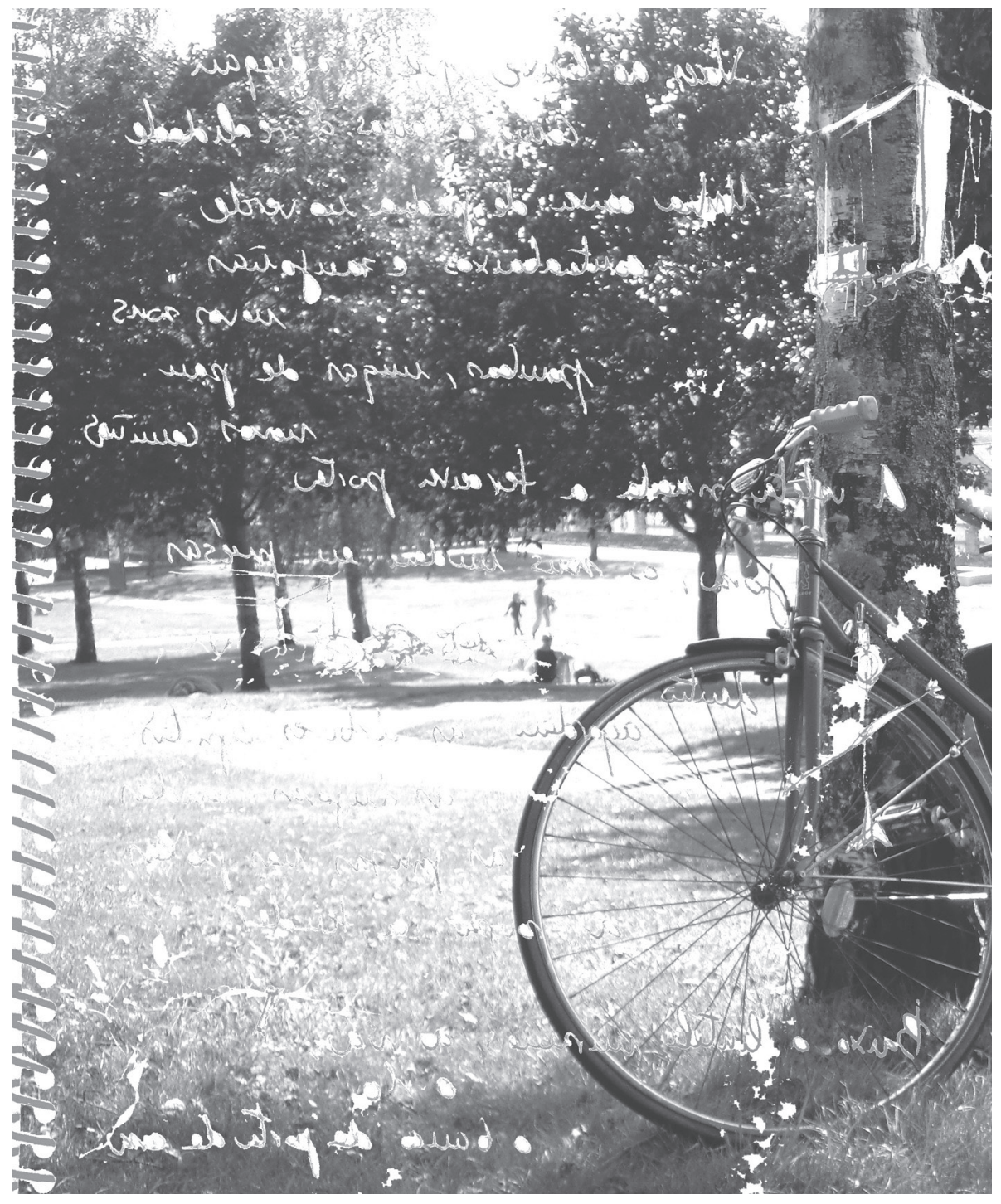


AUTOR: Estella Freire 


\section{Ou o amor, ou a vida, ou a loucura, ou a morte: pequeno ensaio sobre a fractura do ser em Herberto Helder}

[Recibido, 15 maio 2018; aceptado, 10 julho 2018]

http://dx.doi.org/10.15304/bgl.53.5039

RESUMO Este ensaio propõe iniciar uma discussão, através de uma análise que una literatura e filosofia, do poema "Fonte", de Herberto Helder, sobre os topoi do tempo -preponderantemente esse- e do espaço e os seus desdobramentos na escrita do poeta e, assim, questionar e reconstituir a existência humana através da linguagem poética.

PALAVRAS-CHAVE: Herberto Helder; Poética; Hermenêutica.

ABSTRACT The purpose of this essay is to begin a discussion about the topoi of time -mainly- and space in the poem "Fonte" written by Herberto Helder, through an analysis that puts together literature and philosophy to build and argue the human existence thanks to the poetic language.

KEYWORDS: Herberto Helder; Poetics; Hermeneutics.

Vieram ter comigo dos lados do mar. Eram três, eram três mil. Vi que era pão que procuravam ou que não era pão que procuravam. Pus-me a distribuir por eles as minhas palavras: árvore, pássaro, mar, criança, rapariga, mulber. A cada palavra minba eu ia-me esvaziando. Era a vida, a minha vida que se me ia. Eles ficavam incendiados. Nunca tinham pensado que se pudesse comunicar assim coisas próprias. Vieram mais, muitos mais dos lados do mar. Disse-lhes: morte, deus. E caí redondo no chão. Naquele dia ficou instituído o serviço de abastecimento da palavra ao país. Ainda vieram ter comigo, dizendo para eu arranjar outra designação, que aquelas iniciais não podiam ser. Mas eu já habitava plenamente a minha morte, meu planeta desde tenra idade (Ruy Belo, 1997).

O questionamento e o estabelecimento da existência através da linguagem poética -que segue a tradição instituída por Pessoa e pelos adeptos do surrealismo, considerados aqui enquanto influências- Herberto Helder realiza-os através da derruição, na sua escrita, das categorias de espaço e de tempo. 
Junto a elas, derrui-se, ademais, os seus sujeitos poéticos, ou, antes os constrói com substâncias metamorfoseáveis: "Há decomposição e rearranjo, mas não dissolução" (Adorno, 2003: 136).

Sobre a obra de Herberto Helder, no que tange à influência do surrealismo, as suas palavras situam-na numa medida, talvez contraditória, talvez veraz, conforme o libelo publicado no Jornal de Letras e Artes, em maio de 1962, e compilado por Maria Estela Guedes (2010: 131):

Recusam a denominação de surrealistas que alguma crítica, por desatenção e desocupação, lhes atribuiu ou atribuirá. Aceitam do surrealismo todos os primados que se encontram com a dignidade humana e a Alegria de Viver, garantia (consideram) de uma posição ética fundamental diante da mesma vida. Aceitam do surrealismo - para amor e admiração secreta e pública - os actos, obras e morte de alguns exemplificadores que foram surrealistas, quando isso os identificou com a sua pessoal vocação de homens livres. Recusam, finalmente, o surrealismo onde ele não pode ser isso. Recusam-no como escola, como prisão, como antologia, como Chiado.

Acreditam na Poesia como um estilo de vida e, desse modo, estão apaixonadamente dispostos a recusá-la como meio de vida, quer dizer, como acesso a qualquer situação que não tenha a ver com a mesma Poesia, que não seja intimamente correspondente com as coisas dela: ou o Amor, ou a Vida, ou a Loucura, ou a Morte.

Em Herberto Helder, Tempo e Morte são combustível para a reinvenção da existência, através de uma escrita poética que é, ao mesmo tempo, reinvenção do exercício filosófico -leia-se, por exemplo, os seus contos Teorema e Aquele que dá a vida: "Os animais não podem ser humilhados ou destruídos. Há uma espécie de dignidade por falta de recursos morais, uma inteireza fundada no mundo natural" (Helder, 2015: 102). De certa forma, o conto ecoa a ética aristotélica, que considera que os animais não deliberam -ao menos, não através da razão, conclui-se- e, assim como as crianças, não podem ser responsabilizados por suas ações -conquanto as crianças possuam a potencialidade da deliberação e responsabilização, pois, em algum tempo, tornar-se-ão adultas.

Por meio de consciência, o homem alcança o poder ou a vulnerabilidade que o destrói. Escolhe-se a força ou a destruição própria, através da inspiração passada às provas, na enigmática malha da vida, opondo as astúcias do talento a cada repto das coisas. É o génio íntimo de cada um. Génio que não dá paz, que se contenta de si, e se alimenta no seu mesmo exercício. O poder é poder, mais nada. Um bicho, depois de fugir em pânico, assenta as patas na terra e avança 
inteiro, com os cornos baixos, ele todo projectado na violência da cabeça. Passa ou não passa. Passa ou morre. A morte é o seu abismo (Helder, 2015: 102).

Talvez seja a morte o abismo do que há em nós de animalesco: a existência viva no corpo; para além dessa existência, insistimos em mais existir. Será o tempo animal uma reta? E o tempo humano, uma espiral?

Verifica-se, no mesmo conto -Aquele que dá a vida- entrechos hegelianos: a luta de morte, a luta por reconhecimento entre um senhor e um escravo, o poder que é apenas o poder, a escolha entre a força ou a destruição própria.

No Dicionário de Filosofia de Mauthner (1910), lemos um comentário sobre o eterno retorno nietzschiano, no verbete alento:

Se a crença no eterno retorno pudesse se tornar moral, isto é, prática, se por meio dessa crença um único alento pudesse resultar diferente do que sem essa crença, então o retorno exato do mesmo estaria destruído, o objeto da crença seria aniquilado -o que, sem dúvida, pode por vezes ocorrer. [...] )

No enorme poema de seu Zaratustra, Nietzsche deu uma nova expressão poética à antiga fantasia do eterno retorno, [...]. No reino da poesia, também essa representação tem seu lugar. Assim como no reino de um misticismo religioso.

No pensamento, no pensamento com palavras razoavelmente claras, ela é incabível; ela é uma fábula antiquíssima, mas não uma bela fábula [grifo nosso]. Uma bela fábula é a representação da imortalidade [grifo nosso] da alma [...].

...não uma bela fábula. Por um simples motivo: o eterno retorno implicaria um determinismo, o que eliminaria o que há de mais inefável na existência humana, ainda que mortal, que a determina ao indeterminado e constitui a liberdade ética potencial de cada homem, liberdade essa e potencialidade essa que permitem que consideremos a categoria da responsabilidade do agente moral: a nossa capacidade de deliberarmos sobre as nossas ações. Conquanto bela, tal liberdade potencial também pode tornar-se desesperadora. Conquanto desesperadora, ela pode tornar-se motor poético e quebrar, através das palavras, os mecanismos deterministas que cerceiam as nossas existências.

A construção do conto não pode ser contemplada por um resumo, que consistiria em: numa região rural, há uma festa, na qual um touro preto é a atração. Ele será toureado e, provavelmente, morto por um homem cujo estamento lhe permite tal distinção de execução de um rito de morte. Um campesino, porém, toma o seu lugar, mata o touro e, portanto, distinção 
deslocada, provocará a ira do outro homem, cujo intuito, agora, é matar o homem simples. $\mathrm{O}$ entrecho parece singelo, mas é essa capacidade de transformar relatos que poderiam constar em uma gazeta de notícias em realidades alternativas que provoca a aura surrealista na obra herbertiana.

Para avançarmos nesta tarefa, façamos uma leitura interpretativa do poema "Fonte" (recolhido em Anexo), de Herberto Helder, na edição brasileira publicada em São Paulo de Ou o Poema Contínuo, pela A Girafa Editora, em 2006.

A mãe, no poema, confunde-se com a vida, com a natureza, com o íntimo do poeta; é presença oculta e ocultada, velada e que se desvela tanto no sentir da voz poética, quanto em nós. Sabe-se que o poema remete para a experiência do poeta, mas ele transforma-a em experiência primitiva e coletiva. Ao fecharmos os olhos, sabemos que estamos nessa presença escura, terna e tépida. "Ela é a fonte. Eu posso saber que é / a grande fonte / em que todos pensaram.” Essa fonte ecoa em todos nós, que nascemos. E, em dado momento, tornamo-nos filhos de nós mesmos, como Ricardo Reis sentenciou.

Se ela é a fonte, é inconclusa, posto que, rompido o cordão, agora, estamos em outras mãos. Relíquia, relicário, vida suspensa e distendida, "Uma coisa milagrosa que acontecia / ocultamente." Esse útero, esse odre, que matava a sede que ainda não suspeitávamos em nós.

A inteireza dessa fonte feminina diferenciava-a dos demais entes que constituíam o lar; era diferente do elemento masculino presente no lar: "Meu pai lia", e da potencialidade feminina "Minhas irmãs faziam-se mulheres". E, através dessa irradiação, emanação da fonte, que o poeta sabe permanentemente, desse amor doloroso e tranquilo, prenuncia-se a formação de sua sexualidade, de sua diferenciação em ser masculino. Estão presentes elementos simbólicos do feminino e do masculino: a lua, a maçã, símbolos da sexualidade feminina; ponta subtil de ferocidade, prenunciando o princípio da formação de uma masculinidade. O pai, que lê, não é um elemental: ele já está no espectro da técnica e da razão -portanto, do domínio socialmente constituído; enquanto a mãe é, enquanto fonte, um princípio- e um poder natural que transcende tais estamentos.

De certa forma, ao lermos a primeira parte do poema, já sentimos que amar a mãe é amar-se a si, de modo intemporal, pois amamos aquele ser sem o qual não existiríamos, sem o qual não nos poderíamos presentificar. 
"No sorriso louco das mães batem as leves / gotas de chuva"; nele cabem os acasos, os casos, e os causos. "Seu corpo move-se / pelo meio dos ossos filiais", pelos tendões, órgãos, cabeças, corações e mentes, regurgitam nossas existências enquanto "Sentam-se, e estão ali num silêncio demorado e apressado / vendo tudo / e queimando as imagens, alimentando as imagens, / enquanto o amor é cada vez mais forte"; sim, enquanto o amor é cada vez mais forte, esse amaldiçoado e perene algoz. As mães "Pensam os filhos que elas levitam", ou que se materializam, algures.

"E a sua cara está no meio das gotas particulares / da chuva": a existência maternal é, simultaneamente, algo contínuo e pontual, que não conseguimos bem discernir, mas que nos toma e toca inteiramente, como a chuva, como as gotas particulares da chuva, que semelham a um universal, uma umidade única e envolvente.

E, reciprocamente, são os filhos que criam essas coisas, as mães; elas somente se tornam mães após o advento desses filhos em seus corpos e vidas. $\mathrm{E}$ as mães, portanto, são esses "polvos embrulhados nas mãos / e na agudeza de toda a sua vida", seres impossíveis de nos desvencilhar, ora simbióticos, ora parasitários, que perpetuam a vida, rondando a eternidade: " $\mathrm{E}$ através da mãe o filho pensa / que nenhuma morte é possível e as águas / estão ligadas entre si / por meio da mão que toca a cara louca / da mãe que toca a mão pressentida do filho."

O poeta segue numa lírica da plenitude, plenitude tépida da presença da mãe em nós, quase de alumbramento, semelhante ao desvelamento da plenitude do ser na clareira heideggeriana da linguagem: "E por dentro do amor, até somente ser possível / amar tudo, / e ser possível tudo ser reencontrado por dentro do amor."

Morta a mãe, "Ó mãe violada pela noite, deposta, disposta/ agora entre águas e silêncios. / Nada te acorda -nem as folhas dos ulmos, / nem os rios, nem os girassóis, / nem a paisagem arrebatada", qual Ofélia, após a morte do corpo, retorna à natureza, mineraliza-se. $\mathrm{O}$ ulmo, árvore que serve de suporte aos vinhedos, como as mães são o suporte da existência dos filhos, é também utilizada para a confecção de caixões. Além disso, o ulmo é, mitologicamente, a origem da mulher. Segue-se a ausência: "Espero do tempo novo todos os milagres, / menos tu”, e, talvez, a possibilidade de sua superação: 
"Do tempo jovem espero o vinho e o pólen, / outras mãos mais puras / e mais sagazes, / outro sexo, outra voz, outro gosto, outra virtude / inteligente." Pois, enquanto vivemos, ocorrem em nós os frutos da madurez dos ciclos do tempo, da madurez da natureza e da obra humana e outros seres, quiçá, possam nos completar.

Segue-se a ausência e, talvez a linguagem possa preenchê-la: "mas levo os dedos ao teu nome prolongado, / ó cerrada mãe, levo / os dedos vazios - / e a tua morte cresce por eles totalmente," pois só podem tocá-la ao enunciar o seu nome, mágico o bastante para manifestar a mãe ao poeta.

$\mathrm{Na}$ quarta parte do poema, no preâmbulo da noite, o filho só, homem madurado pela ausência-presença da mãe -talvez tomado pelo vinho, entre a pulsão de vida e morte que não se converterá em ato amoroso, parece aludir a um ato de masturbação, à sexualidade latente que as mães transmitem aos filhos: "E quando o esplendor invade as bagas / venenosas, o silêncio dos dedos / docemente o procura.".

O filho só, homem madurado pela ausência-presença da mãe, talvez tomado pela razão "Um dia começa a alma", atinge a figura materna, a cabra. Neste trecho, várias aliterações marcam o frêmito da humana razão, que aparenta brilhar sobre a natureza "no sangue espesso e maduro do bicho maravilhoso". "Um dia começa o amor louco. / Porque a cabra / é uma coisa materna e antiga, / À noite o trigo irrompe da terra." Não será o amor louco o perpetuar de nossa existência, filialmente, indistinta e intestina? A cabra é bela, mas é animalesca, como nós; é materna, porque provê, é antiga, como as mães. Herberto Helder parece retomar o mito de Amálteia, a mulher "que amamentou Zeus recém-nascido no monte Ida, em Creta, e o criou ocultamente para livrá-lo da perseguição de Cronos, seu pai, ansioso por devorá-lo" (Kury, 2003: 27).

O filho só, homem madurado pela ausência-presença da mãe, talvez tomado pela linguagem: "-Mal se levanta a cabra sobre as letras puras, sobre / a forma árdua e amarga da melancolia”, pode tentar manifestar a mãe, presente na poesia.

Pondera o poeta que estamos vinculados aos frutos plenos dos ciclos temporais: "E se morrer é a alta vocação das manhãs marcadas pelas uvas / -peço, 
mãe um dia / composta sobre a veemente confusão das forças / e dos números, que resguardes / entre as descuidadas dobras de pedra / o fulgor de onde plátanos e aves recebiam / a doce e dolorosa vida / da beleza." O plátano -ou sicômoro- é uma árvore associada aos ritos de morte; suas folhas possuem o formato de coração. Entretanto, ela também é uma espécie de figueira, de frutos maduros, avermelhados e extremamente frondosa, que abriga inúmeros animais, principalmente aves. Além disso, é uma árvore associada à redenção, que serviu de apoio à Zaqueu para observar o Cristo. As imagens e metáforas utilizadas pelo poeta remetem à seiva vegetal e ao mundo mineral, aos ciclos temporais, a um possível retorno, seja pela natureza, seja pela linguagem, da mãe.

Um possível retorno: o filho fez-se pai? "Tudo o que se diga está vivo na frescura de um coração / novo. Por isso o ouro, o inseguro passo / de um dia que traz a morte em sua intensa / juventude", pois cada instante de vida está prenhe da morte, "roça a forma do espírito / em que tu mesma te buscavas -quente e rápida / em nós, no equilibrado idioma / de fomes e sorrisos que nunca / se decifram".

No universo íntimo que percorremos ao fecharmos nossos olhos, a encontramos: "Quando aperto as pálpebras / ou descubro o teu nome como uma paisagem, / só há grutas virgens onde os candelabros se apagam." $\mathrm{O}$ poeta parece dizer: onde posso encontrar-te, senão em mim, em que cravastes tuas marcas indelevelmente tatuadas? Talvez a linguagem permita uma aproximação: "Mãe, pouco resta de ti na exaltação deste mundo. Às vezes / misturas-te um pouco nos terrores da noite ou olhas-me, / vertiginosa e triste, através / das palavras".

E, onde costumavas estar, apenas a visão da memória permanece: "No outro lado da mesa estás inteiramente / morta.". "Não podes levantar-te dos retratos antigos / onde procuro afogar-me como uma criança / nocturna.", pois as fotos de nossos amados, mortos, tragam-nos como os turbilhões de um rio, ou as vagas do mar. Tampouco, está a mãe ao seu lado, sob "uma árvore inspiradora e eterna" como o sicômoro já citado.

“Tu desapareceste. É um erro / das musas distraídas.”; posto, parece dizêlo, sou poeta, o tempo não me atinge, logo, mãe, tu és. Mas, não há guindaste que resgate essa Ofélia matriarcal, e continuamos vivos, conhecendo "grandes 
casas onde não habitas", sentindo odores, devorando laranjas, "sentindo o gosto da vida, desde a garganta às mais finas raízes das vísceras. Tu desapareceste." Como é possível continuarmos, se a nossa permanência nos foi dada pela mãe? Se a sua seiva ainda está em nós?

“-talvez / pudesses salvar-me como uma palavra pode / salvar um pensamento, ou uma / breve música pode acordar do abismo inocente / da noite / um instrumento encerrado em suasnas cordas extenuadas." Talvez, pudesse a mãe, ao reviver, fazer-nos viver em plenitude.

Desta análise sucinta do poema de Herberto Helder, podemos chegar a algumas assunções. Uma delas é que a poesia possui, em si, a capacidade de fazer da fractura da existência um continuиm entre o velado e o desvelado: transcende, assim, qualquer conceito de verdade e concomitantemente, atinge o absoluto da existência humana: a linguagem. Ou, dito de outro modo, o discurso apofântico não basta para apreender a existência. Faz-se necessária a poesia.

Esse é o jogo hermenêutico presente no mito de Édipo, o herói que é 12 destruído pela sua bybris pelo conhecimento adquirido através da linguagem. Mas que espécie de conhecimento é esse?

\section{Para Eduardo Lourenço (1987: 32),}

Édipo pensou que uma fórmula era uma solução. E ela era só uma dificuldade. Que bastava dizer uma só vez HOMEM e o terror e os monstros se sumiriam para sempre. Foi o primeiro humanista sincero mas abstracto. A verdade é que os monstros voltam sempre. [...] Impossível aceitar como Édipo que tudo está feito só porque descobrimos a fórmula que permite que tudo se faça.

[...] A Esfinge não é um enigma resolvido nem a resolver nos séculos futuros. A Poesia não é uma árvore morta nem a fazer florir nas colinas de amanhã. É a resolução que damos à história, aos encontros, às promessas, de cada vez que consentimos descer das palavras à dificuldade dos actos. Ou subimos dos actos à corola mágica das palavras com que os arrancamos à certa desolação do tempo e da morte.

O homem é mais que o destino e os deuses, isso já nos disse Sófocles, ainda que de modo conflituoso, com Édipo, o herói, não só do destino, como muitos pensam, mas do conhecimento, da fome e da bybris pelo conhecimento, senhor, servo e amante da esfinge-oráculo. Prossegue Lourenço (1981: 60): 
É natural e óbvio aceitar que as coisas são reais e é em função dessa quotidiana convicção que a humanidade existe. Mas já o é menos desejar a realidade das coisas como única realidade para se libertar da própria e enigmática irrealidade e alcançar assim a única felicidade de que somos capazes.

Assim posto, que outras realidades podemos presumir? Qual é a linguagem que as apreende? "Que linguagem pode servir à nomeação da realidade que somos senão aquela que por autonomásia ${ }^{1}$ já nos é devolvida como suprema Criação? É poeticamente que habitamos o mundo ou não o habitamos" (Lourenço, 1987: 38).

Eduardo Lourenço (1981: 59-60), na sua análise de Pessoa e, em particular, de seu heterônimo Ricardo Reis, corrobora algumas de nossas assunções, nessa "tentativa de salvar do universal desastre da Vida o que de anónimo sorriso nela haver"; e comenta Ricardo Reis,

$O$ resto passa,

E teme a morte,

Só nada teme ou sofre a visão clara

E inútil do Universo.

Para dar vida a essa aspiração, ou antes, como aspiração dela, surgiu justamente Reis, trazendo colado ao rosto, além da insolúvel questão de que é fictícia resposta, uma outra menos espectacular, mas de não menos imperativa urgência: a de mostrar, por assim dizer, com a prova nas mãos, que Poesia é mais que Destino e Deuses. Submeteram-se o Tempo e a Morte [grifo nosso] (as únicas 'realidades' que impedem a Consciência de se sentir existente) à estratégia de Pessoa, encerrando-se enquanto Reis, na forma que os supera? Nem o esforço para fingir que nada são, nem o inverso de crer que são tudo e viver, apesar dos deuses, como se o não fossem, aboliram o inomeável absurdo de que são feitos.

Na nossa perspectiva, a via estética aproxima-se, aqui, da via filosófica: questionar essa quotidiana convicção é o mote do filósofo; transfigurá-la, o do poeta. Em Reis, por exemplo, o mito é o ponto de fuga do que é comumente aceito, Tempo e Morte postam-se como limites, cuja distorção se torna necessária para o existir.

1 O termo autonomásia não está dicionarizado (não confundir com antonomásia). Pode-se concluir que Eduardo Lourenço, neste trecho de Tempo e Poesia (1987: 38), pensa o processo metonímico presente na linguagem poética como um circuito de autoalimentação linguística, que remodela $\circ$ mundo que habitamos e o modo como o habitamos. 
Para Álvaro de Campos, "Aquilo que faz que haja deuses e Deus e Destino. / Aquilo que faz que haja ser para que possa haver seres, / Aquilo que subsiste através de todas as formas" nada mais é que o mais criador e mítico dos seres: o homem -e suas palavras.

Analisando a fractura da existência em relação à linguagem, Rosa Maria Martelo (2010: 17-18) comenta Agamben:

Ao decodificar o enigma da Esfinge, Édipo teria apagado a fractura original da presença, no que esta tinha de co-pertença originária da presença e da ausência (distância), e teria rasurado o abismo que se abre entre o significante e o significado. Nessa medida, talvez todas as dimensões organicistas da poesia, o seu equilíbrio no plano discursivo, sejam formas de contrabalançar a permanente desconfiança relativamente ao modo como a linguagem produz sentido. Talvez derivem da ousadia de olhar de frente essa fractura, e mesmo de se tentar falar a partir dela. Assim, a poesia tenderia a ser uma experiência de limites, dos limites da linguagem e dos mundos que ela permite designar. E também por isto, ou mesmo principalmente por isto, a poesia vive de uma permanente tensão entre o equilíbrio e o desequilíbrio, que não pode deixar de incorporar.

É preciso notar que Agamben, ao falar de presença, dialoga diretamente com Heidegger. O percurso heideggeriano até a linguagem é extenso, mas podemos destacar que será através da leitura de Nietzsche e de Hördelin, do impacto do lógos poético na busca pelo ser, realizada pelo Dasein, que se plenificará seu projeto onto-hermenêutico, no qual o próprio lógos poético da escrita heideggeriana abrirá a clareira em que o ser manifesta-se aos entes.

A escritura de Herberto Helder incorpora essa tensão e esse desvelamento. Ela busca o ser que está na escrita, transformando a existência em via poética.

\section{Comentário Final}

Como dito acima, a proposta deste trabalho é discutir a fractura do ser, os topoi do tempo -em maior espectro- e do espaço em Herberto Helder, através de uma análise literário-filosófica. Na poesia de Herberto Helder, como salienta Martelo (2010: 85), "a morte sempre teve um lugar”, e é através de poemas com essa temática -mas não só- que o poeta conforma e reconforma esses conceitos. Seguindo a tradição instituída por Pessoa e pelos adeptos do 
surrealismo, Herberto Helder derrui, em sua escrita, as categorias de espaço e tempo. Junto a elas, derruí-se, ademais, os seus sujeitos poéticos, ou, antes os constrói com substâncias metamorfoseáveis. Tentamos, neste ensaio, apontar algumas das possíveis fontes que construíram a escrita de Herberto Helder sobre o tema.

Rosely de Fátima Silva Universidade de São Paulo 


\section{Anexo}

Poema "Fonte", em Ou o Poema Contínuo (Herberto Helder, 2006: 43-55).

\section{FONTE}

$I$

Ela é a fonte. Eu posso saber que é

a grande fonte

em que todos pensaram. Quando no campo

se procurava o trevo, ou em silêncio

se esperava a noite,

ou se ouvia algures na paz da terra

o urdir do tempo-

cada um pensava na fonte. Era um manar

secreto e pacifico.

Uma coisa milagrosa que acontecia

ocultamente.

Ninguém falava dela, porque

era imensa. Mas todos a sabiam

como a teta. Como o odre.

Algo sorria dentro de nós.

Minhas irmãs faziam-se mulheres

suavemente. Meu pai lia.

Sorria dentro de mim uma aceitaçãa

do trevo, uma descoberta muito casta.

Era a fonte.

Eu amava-a dolorosa e tranquilamente.

A lua formava-se

com uma ponta subtil de ferocidade, e a maçã tomava um princípio

de esplendor.

Hoje o sexo desenhou-se. O pensamento

perdeu-se e renasceu.

Hoje sei permanentemente que ela

é a fonte. 
No sorriso louco das mães batem as leves

gotas de chuva. Nas amadas

caras loucas batem e batem

os dedos amarelos das candeias.

Que balouçam. Que são puras.

Gotas e candeias puras. E as mães

aproximam-se soprando os dedos frios.

Seu corpo move-se

pelo meio dos ossos filiais, pelos tendões

e órgãos mergulhados,

$e$ as calmas mães intrínsecas sentam-se

na cabeças filiais.

Sentam-se, e estão ali num silêncio demorado e apressado,

vendo tudo,

e queimando as imagens, alimentando as imagens,

enquanto o amor é cada vez mais forte.

E bate-lhes nas caras, o amor leve.

$O$ amor feroz.

$E$ as mães são cada vez mais belas.

Pensam os filhos que elas levitam.

Flores violentas batem nas suas pálpebras.

Elas respiram ao alto e em baixo. São

silenciosas.

E a sua cara está no meio das gotas particulares

da chuva,

em volta das candeias. No contínuo

escorrer dos filhos.

As mães são as mais altas coisas

que os filhos criam, porque se colocam

na combustão dos filhos, porque

os filhos estão como invasores dentes-de-leão

no terreno das mães.

$E$ as mães são poços de petróleo nas palavras dos filhos,

e atiram-se, através deles, como jactos

para fora da terra.

$E$ os filhos mergulham em escafandros no interior

de muitas águas,

e trazem as mães como polvos embrulbados nas mãos

e na agudeza de toda a sua vida.

E o filho senta-se com a sua mãe à cabeceira da mesa, e através dele a mãe mexe aqui e ali, 
nas chávenas e nos garfos.

E através da mãe o filho pensa

que nenhuma morte é possível e as águas

estão ligadas entre si

por meio da mão dele que toca a cara louca

da mãe que toca a mão pressentida do filho.

E por dentro do amor, até somente ser possivel

amar tudo,

e ser possivel tudo ser reencontrado por dentro do amor.

\section{III}

Ó mãe violada pela noite, deposta, disposta

agora entre águas e silêncios.

Nada te acorda - nem as folhas dos ulmos,

nem os rios, nem os girassóis,

nem a paisagem arrebatada.

- Espero do tempo novo todos os milagres,

menos $t u$.

Corres somente no meu sangue memoriado

e sobes, carne das palavras outra vez

imperecíveis e virgens.

- Do tempo jovem espero o vinho e o pólen, outras mãos mais puras

e mais sagazes,

e outro sexo, outra voz, outro gosto, outra virtude

inteligente.

- Espero cobrir-te novamente de júbilo, ó corola do canto.

Mas tu estarás mais branca com a boca selada

pelas pedras lisas.

E sei que terei o amor e o pão e a água

e o sangue e as palavras e os frutos.

Mas tu, ó rosa fria,

ó odre das vinhas antigas e limpas?

Do tempo novo espero

o sinal ardente e incorrupto,

mas levo os dedos ao teu nome prolongado,

ó cerrada mãe, levo

os dedos vazios -

e a tua morte cresce por eles totalmente. 
IV

Mal se empina a cabra com as patas traseiras

na lua, e o cheiro a trevo

no focinho puro, e os cornos no ar

arremetendo aos astros. E sobre a solidão das casas,

entre o sono e o vinho derramado,

curvam-se os ágeis

cascos de demónio.

E o sonâmbulo desejo do coração

absorve tudo ao alto numa vertigem

tenebrosa.

E quando o esplendor invade as bagas

venenosas, o silêncio dos dedos

docemente o procura.

Então as veias mudam a conjunção

suspensa

do sangue que ascende e que mergulba.

Uma estrela feroz queima a fronte de apolo.

$E$ as mandíbulas, os pés, a invenção, a loucura, o sono

secreto, a beleza terrivel

espalbam sobre nós a branca

luz violenta.

Um dia começa a alma, e um caçador atinge

a cabra fremente no flanco

com uma flecha viva.

Cantamos devagar o espirito dos livros.

E brilha toda a noite, no sangue espesso

e maduro do bicho

maravilhoso,

o dardo do caçador.

Um dia começa o amor louco.

Porque a cabra

é uma coisa materna e antiga.

À noite o trigo irrompe da terra.

E sob a nossa boca roda a imagem do mundo, rosácea

abstracta, ou rosa aglomerada

e ardente. Na penumbra das casas as mulberes

respiram - surdas, lentas, cegas

de beleza. E no sono as palavras

são mortalmente confusas. 
- Mal se levanta a cabra sobre as letras puras, sobre

a forma árdua e amarga da melancolia.

V

Apenas te digo o ouro de uma palavra no meio da névoa,

formosura inclinada sobre a cinza descerrada

e o frio dos retratos.

E espero que a seiva ascenda a um puro gosto

de reaver tua grave cabeça de mãe

com platina entre a aragem. Que se inspire na seiva

o vermelho de uma face

adormecendo no vinho, acordando

para o início das primaveras.

Peço que os dedos não esqueçam o pão e a tristeza,

e a boca vibre como um pensamento

na substância de um instante

carnal, irremovível.

E se morrer é a alta vocação das manhãs marcadas pelas uvas

- peço, mãe um dia

composta sobre a veemente confusão das forças

e dos números, que resguardes

entre as descuidadas dobras de pedra

o fulgor de onde plátanos e aves recebiam

a doce e dolorosa vida

da beleza.

Rente ao tempo que nos cobria

de previsão e silêncio,

arrefecem os sentidos sobre o teu rosto selado.

Pequena e imensa coisa no alto das águas,

no fundo de sementes desmemoriadas - mãe

engolfada no leite renascente,

para ti se elevam os lábios tocados pelo sumo

incompleto, o sono da próxima

incontida primavera.

Tudo o que se diga está vivo na frescura de um coração

novo. Por isso o ouro, o inseguro passo

de um dia que traz a morte em sua intensa

juventude, roça a forma do espírito 
em que tu mesma te buscavas - quente e rápida

em nós, no equilibrado idioma

de fomes e sorrisos que nunca

se decifram.

Num lugar onde a sombra é gémea

do fogo irrevelado, não há

morte que se não destine a um escarlate

de rosa. Nunca se adormece

que não seja para ler um estuante anúncio

nas pálpebras que se apagam.

Nasces da melancolia, e arrebatas-te.

Como os bichos nascem da matéria dos seus dias,

Como os frutos vacilam no bojo das auroras,

e se embebem até que o tempo os faz

violentos,

cerrados,

palpáveis.

$V I$

Estás verdadeiramente deitada. É impossível gritar sobre esse abismo onde rolam os cálices transparentes da primavera

de há vinte e dois anos. Quando aperto as pálpebras ou descubro o teu nome como uma paisagem, só bá grutas virgens onde os candelabros se apagam.

Mãe, pouco resta de ti na exaltação do mundo. Às vezes misturas-te um pouco nos terrores da noite ou olhas-me, vertiginosa e triste, através das palavras.

No outro lado da mesa estás inteiramente morta. Parece que sorris de leve no meu pensamento, mas sei que é apenas a solidão espantada. Como pudeste morrer tão violenta e fria, quando os meus dedos começavam a agarrar-te a cabeça inclinada dentro das luzes? Não podes levantar-te dos retratos antigos onde procuro afogar-me como uma criança nocturna. E não atravessaremos juntos as cidades redentoras, 
perdidos um no outro, sorrindo,

como se estivéssemos debaixo de uma árvore inspirada e eterna.

Conbeço algumas cidades da europa e a fantasia vagarosa da cidade da minha infância.

Tu desapareceste. É um erro

das musas distraídas. Não há guindaste que te levante

do coração das águas,

onde apodreceste envolvida no balo do teu amor invisivel,

ou recolbida na tua carne rápida, ou

ligeiramente tocada pelo ardor

de uma existência pura. Conbeço grandes casas

onde não babitas, flores que cheiro, tarefas

silenciosas que cumpro bumildemente, e luzes,

instrumentos de música,

laranjas que devoro sentindo o gosto da vida desde a garganta

às mais finas raizes das vísceras. $T u$

desapareceste.

Imagino que seria possível tocares porventura

a minha boca. Tocares-me tão viva ou tão misteriosamente

que eu estremecesse nas traves

da cega inspiração. Poderias estar vergada sobre os meus

ombros até que as lágrimas

na minha boca se confundissem com a ansiosa subtileza

dos teus dedos, e eu me sentisse

perdido entre os pilares e os túneis das cidades

ressoantes.

Depois talvez pudesses vir com o rosto um pouco coberto de poeira, e os olhos delicados de mulher restituída,

e os pés brilhando sobre os caminhos do meu silêncio exaltado

-talvez

pudesses salvar-me como uma palavra pode

salvar um pensamento, ou uma

breve música pode acordar do abismo inocente

da noite

um instrumento encerrado nas cordas extenuadas. 


\section{Referências bibliográficas}

Adorno, Theodor W. 2003. Notas de Literatura I. São Paulo: Duas Cidades, Editora 34.

Aristóteles. 2008. Física. Madrid: Editorial Gredos, S. A. U.

Aristóteles. 1993. Poética. São Paulo: Ars Poetica.

Belo, Ruy. 1997. Homem de Palavra[s]. Lisboa: Editorial Presença.

Guedes, Maria Estela. 2010. A obra ao rubro de Herberto Helder. São Paulo: Escrituras Editora.

Heidegger, Martin. 2005. Carta sobre o humanismo. São Paulo: Centauro.

Heidegger, Martin. 2012. Ser e tempo. Campinas, SP: Editora da Unicamp; Petrópolis, RJ: Editora Vozes.

Helder, Herberto. 2015. Os Passos em Volta. Porto: Porto Editora.

Helder, Herberto. 2006. Ou o Poema Contínuo. São Paulo: A Girafa Editora.

Knox, Bernard. 2002. Édipo em Tebas. São Paulo: Editora Perspectiva.

Knox, Bernard. 1966. The Heroic Temper. Berkeley and Los Angeles: University of California Press.

Kury, Mário da Gama. 2003. Dicionário de mitologia grega e romana. Rio de Janeiro: Jorge Zahar Ed.

Lourenço, Eduardo. 1981. Fernando Pessoa Revisitado: Leitura Estruturante do Drama em Gente. Lisboa: Moraes Editores.

Lourenço, Eduardo. 1987. Tempo e Poesia. Lisboa: Relógio d'Agua Editores Lda.

Martelo, Rosa Maria. 2010. A Forma Informe, leituras de poesia. Lisboa. Assírio e Alvim.

Mauthner, Fritz. 1910. Wörterbuch der Philosophie. Munique e Leipzig: Georg Muller [trechos traduzidos por Laura Moosburger e Márcio Suzuki].

Pessoa, Fernando. 1986. Obra Poética. Rio de Janeiro: Editora Nova Aguilar.

Pessoa, Fernando. 1976. Obras em Prosa. Rio de Janeiro: Editora Nova Aguilar.

Perrone-Moysés, Leyla. 2001. Fernando Pessoa, aquém do eu, além do outro. São Paulo: Martins Fontes.

Sófocles. 2004. Édipo Rei. São Paulo: Editora Perspectiva. 